\title{
Nadir görülen bir omuz ağrısı nedeni: Spinoglenoid çentikte ganglion kisti
}

\author{
M. Faik Seçkin' ${ }^{1}$ Adnan Kara ${ }^{1}$, Haluk Çelik ${ }^{1}$, Mehmet Mesut Sönmez ${ }^{1}$, İran Öztürk¹
}

\begin{abstract}
ÖZET:
Nadir görülen bir omuz ağrısı nedeni: Spinoglenoid çentikte ganglion kisti Ganglion kistleri ayak, el ve el bileğinde görülen en sık yumuşak doku tümörleridir. Omuz ekleminden kaynaklanan ganglion kisti ise sık görülmez. Sağ omuzda ağrı şikayeti ile başvuran, yapılan incelemelerde atipik yerleşimli ganglion kisti tanısıyla ameliyat edilen ve histopatolojik tanısı ganglion kisti olan kırkbeş yaşındaki erkek hasta cerrahi sonucu ile birlikte sunuldu. Ameliyat sonrası takiplerinde hastanın şikayetlerinin düzeldiği görüldü.

Anahtar kelimeler: Ganglion kisti, omuz, ağrı

ABSTRACT:

A rare cause of shoulder pain: Ganglion cycts in the spinoglenoid notch Although ganglion cysts are most common soft tissue tumors of foot, hand and wrist, they are rarely seen in shoulder girdle. In this manuscript it is aimed to present a patient who was admitted with shoulder pain due to atypically located ganglion cyct. The symptoms were relieved after excision of lesion.
\end{abstract}

Key words: Ganglion cycst, shoulder, pain

Ş.E.E.A.H. Tıp Bülteni 2013;47(3):151-153
'Şişli Etfal Eğitim Ve Araştırma Hastanesi Ortopedi ve Travmatoloji Kliniği, İstanbul-Türkiye

Yazışma Adresi / Address reprint requests to: Uzm. Dr. Adnan Kara, Şişli Etfal Eğitim Ve Araştırma Hastanesi Ortopedi ve Travmatoloji Kliniği, İstanbul-Türkiye

Telefon / Phone: +90-212-373-5000/6515

E-posta / E-mail:

dradnankara@gmail.com

Geliş tarihi / Date of receipt: 23 Ekim 2012 / October 23, 2012

Kabul tarihi / Date of acceptance: 15 Kasım 2012 / November 15, 2012

\section{GiRiş}

Omuz ağrısının ve fonksiyon bozukluğunun nedenleri arasında nadir de olsa ganglion kistleri yer almaktadır. Bu hastalık, omuz sıkışma sendromları, glenohumeral instabilite, rotator manşet hastalıkları, tendinitler, adheziv kapsülitler, travma, servikal radikülopatiler, neoplazmlar ve dejeneratif hastalıklar ile birlikte omuz ağrısı ayırıcı tanısında göz önüne alınmalıdır. Bu olgu sunumunda spinoglenoid çentikte yerleşmiş olan ganglion kisti nedeniyle omuzda ağrı şikayeti ile kliniğimize başvuran bir hasta değerlendirildi.

\section{OLGU}

Kırkbeş yaşında erkek hasta polikliniğimize 6 aydır devam etmekte olan sağ omuz ağrısı şikayetiyle başvurdu. Ağrının karakteri derin ve yaygın olmasıydı. Altı ay önce başka bir merkezde subakromail bölgeye kortizon enjeksiyonu yapıldığı öğrenildi. Hastanın fizik muayenesinde, ağrının omuzun posterior ve lateral bölgelerinde lokalize olduğu ayrıca

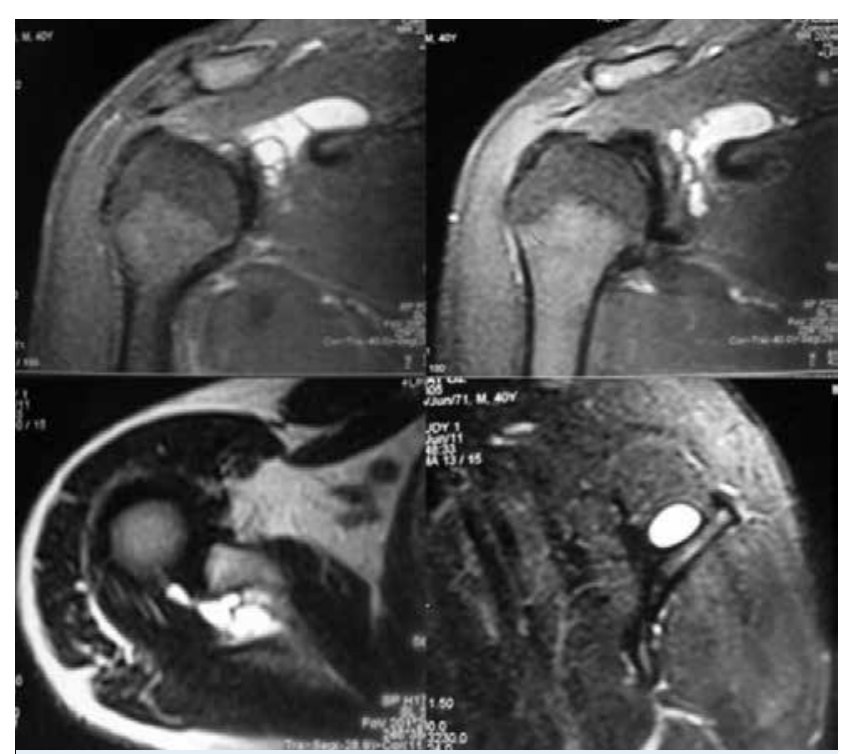

Resim 1: Ganglion kistinin MRI görüntüleri 


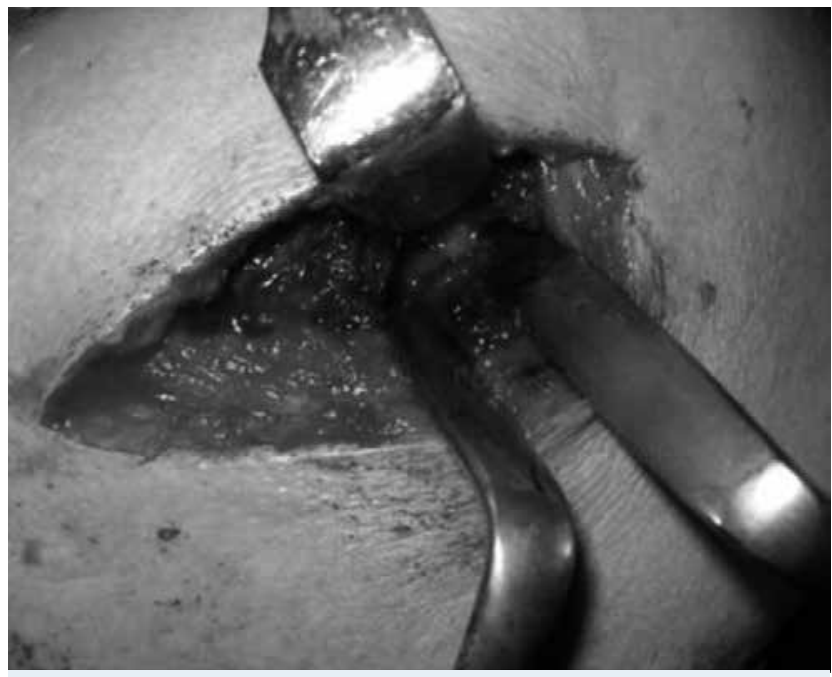

Resim 2: Cilt insizyonu ve ganglion kistinin görüntüsü

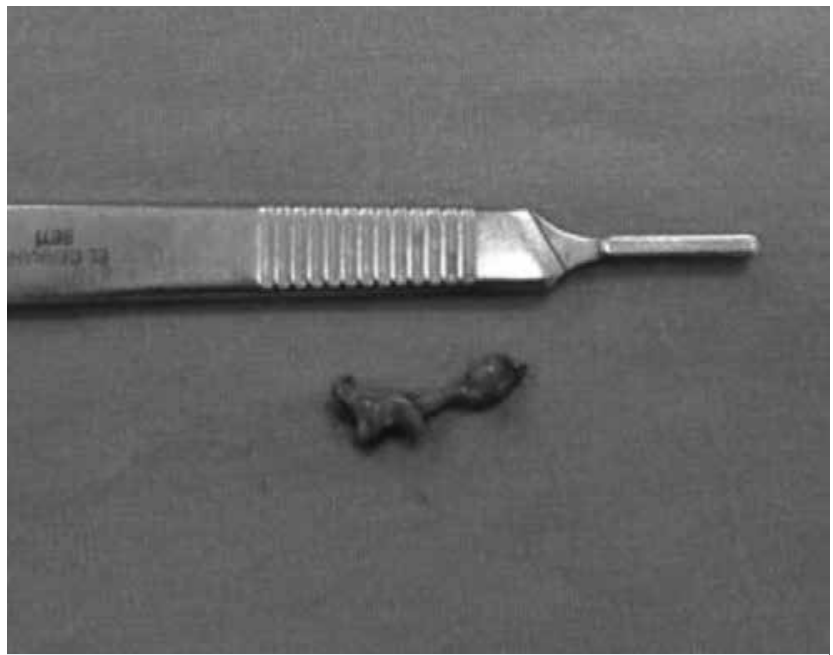

Resim 3: Çıkartılan ganglion kistinin makroskopik görüntüsü

kola ve boyna doğru yayıldığı görüldü. Spinoglenoid çentik üzerinde palpasyonla ağrı tespit edildi. Kolun adduksiyona getirilmesiyle ağrının arttığı görüldü. Nörolojik defisit saptanmayan olguda, omuz hareket açıklığının ve kas gücünün normal olduğu saptandı.

Direk grafilerinde özellik saptanmayan hastanın çekilen manyetik rezonans görüntüleme (MRI) de spinoglenoid çentikte ganglion kisti saptanması (Resim 1) ve şikayetlerinin devam etmesi üzerine açık cerrahi girişim uygulanarak kist eksize edildi.
Genel anestezi altında hasta sol lateral dekübit pozisyonunda iken, sağ omuz posteriordan spinoglenoid çentik üzerinden $7 \mathrm{~cm}$ 'lik transvers cilt insizyonuyla girildi (Resim 2). Akromionun posterolateral köşesinin medialinden başlayarak deltoid,spina skapula üzerinden ayrıldı. Supraskapular sinir, spinoglenoid çentikten infraspinatus kasına sinir lifi verene kadar takip edildi. Spinoglenoid çentikte $2.5 \times 2 \mathrm{~cm}$ boyutlarında medial sınırları belirgin kistik kitle eksize edildi (Resim 3). Kitlenin supraskapular sinirin yakınında olduğu ancak belirgin bir bası oluşturmadığı görüldü. Eksize edilen kitlenin histopatolojik sonucu ganglion kisti olarak rapor edildi. Hastanın yapılan kontrollerinde ağrısının geçtiği ve omuz hareket açıklığının normal olduğu gözlendi.

\section{TARTIŞMA}

Ganglion kistleri eklem ve tendon kılıfı üzerinde, bunların sinovyasının fıtıklaşmasıyla oluşan kistik oluşumlardır. Nadiren tendon fibrilleri arasından da kaynaklanabilirler. Sıklıkla kadınlarda, 30-50 yaşlar arasında görülür. Travma ile her zaman ilişkili değildir (1). Bulundukları yer ve kaynaklandıkları anatomik bölgelere göre intraosseöz, subperiostal ve yumuşak doku kistleri olarak adlandırılırlar (2). Klinik olarak orta şiddette ağrı, intraossez tipi hariç lokal şişlik ve ele gelen kitle ile karakterizedirler. En sık el ve el bileğinden kaynaklanmasına rağmen, daha az sıklıkta olmak üzere proksimal tibiofibular eklemde, diz posteriorunda Baker kisti şeklinde, ayak bileğinde görülebilir (3). Omuz ekleminden kaynaklanan ganglion kisti olgularına literatürde nadir rastlanılmaktadır. Omuz ganglion kistlerine artroskopik kombine açık cerrahi uygulanan bazı olgularda kapsülolabral yırtıklara rastlanmıştır $(4,5)$. Bu bulgular kistin etyolojisinde tek veya kronik tekrarlayan travmanın rolü olduğu düşüncesini arttırmaktadır. Biz hastanın ameliyat öncesi çekilen MR görüntülemesinde intraartiküler patoloji saptamadığımızdan dolayı artroskopik girişim uygulamadık. Literatürde omuz ekleminden kaynaklanan, özellikle spinoglenoid çentikte oluşan ganglion kistlerinin supraskapular sinire bası yaptığı gözlenmiştir (6-8). Spinoglenoid notch ta ki bu kistlerin izole infraspinatus paralizisi ve buna bağlı eksternal rotasyon kısıtlılığına neden olan supraskapular 
sinir tutulumu yapabileceği bilinmektedir (9). Bizim olgumuz için ameliyat öncesi yapılan EMG de herhangi bir bulgu saptanmamış, operasyon esnasındaki eksplorasyonda da supraskapular sinire bası gözlenmemiştir. Bunun nedenini ganglion kistinin nörolojik defisit yapacak büyüklüğe ulaşmadan erken teşhis ve tedavi edilmesine bağlıyoruz.

Ganglion kistlerinin ayırıcı tanısı tüberküloz, romatoid tenosinovit, lipom, fibrom, osteom, sarkom ve anevrizmayı içermelidir (10). Manyetik rezonans görüntüleme, yumuşak doku tümörlerinin anatomisini belirlemede ve sinyal karakteristiklerine göre kesin tanıda son derece yararlı bilgiler vermektedir. T2 ağırlıklı incelemelerde, tümör lezyonu kaplayan lobüler, multiseptalı, hiperintens sinyal artışı ile karakterize koleksiyonlar ganglion kistine spesifiktir (3). Kesin tanı iğne aspirasyonunda parlak, sarımsı, koyu, jelatinimsi materyalin aspirasyonu ile konur. Biz de olgumuzda çekilen MR görüntüleme sonucuna göre ganglion kisti ön tanısı koyduk.

\section{KAYNAKLAR}

1. Cummins CA, Messer TM, Nuber GW. Suprascapular nerve entrapment. J Bone Joint Surg Am 2000;82(3):415-24.

2. Gül M, Özkaya U, Parmaksızoğlu A, Sökücü S, Kabukçuoğlu Y. Ganglion kisti ve neden olduğu düşük ayak olgusu-olgu sunumu. Şişli Etfal Hastanesi Tıp Bülteni 2008;42(4):25-7.

3. Akman $S$, Gür B, Sülün T, Aksoy B. A case of a ganglion cyst originating from the hip joint and surgical outcome. Acta Orthop Traumatol Turc 2002;36(1):76-8.

4. Tirman PF, Feller JF, Janzen DL, Peterfy CG, Bergman AG. Association of glenoid labral cysts with labral tears and glenohumeral instability: radiologic findings and clinical significance. Radiology 1994;190(3):653-8.

5. Legaye J, Redier S. Synovial cyst of the hip. Apropos of a case manifested by venous compression. Acta Orthop Belg 1995;61(2):140-3.
Ganglion kistlerinin tedavi yöntemleri arasında cerrahi ve cerrahi olmayan yöntemler vardır. Semptomatik olan olgularda kesin tedavi eksizyondur (5). Biz olgumuzda ganglion kistinin yerleşiminin atipik olması, iğne aspirasyonu ile ulaşım zorluğu ve rekürens riski nedeniyle açık cerrahi girişim uyguladık. Literatürde rekürenslerin oldukça yüksek oranda (\%40) görüldügü bildirilmiştir (10). Takiplerimizde hastamızda rekürrens saptanmamıştır. Total eksizyondan sonra görülen yüksek rekürens oranları atipik anatomik lokalizasyonlardaki ganglion kistlerinde yeterli eksizyon yapılamamasına bağlanabilir.

Sonuç olarak omuz ağrısının ayırıcı tanısında ganglion kistleri nadir olarak görülsede akılda tutulmalı, ayırıcı tanıda MR görüntülemeden faydalanılmalıdır. Atipik yerleşimli sinir komşuluğu olan vakalarda nörolojik defisit gelişmeden müdahale yapılmalı, iğne aspirasyonu ile ulaşım zorluğu ve rekürens riski nedeniyle açık cerrahi eksizyon öncelikli tedavi seçenekleri arasında olmalıdır.

6. Hirayama T, Takemitsu Y. Compression of the suprascapularnerve by a ganglion at the suprascapular notch. Clin Orthop 1981;155:95-6.

7. Moore TP, Fritts HM, Quick DC, Buss DD. Suprascapular nerve entrapment caused by supraglenoid cyst compression. J Shoulder Elbow Surg 1997;6(5):455-62.

8. Thompson RC Jr, Schneider W, Kennedy T. Entrapment neuropathy of the inferior branch of the suprascapular nerve by ganglia. Clin Orthop 1982;166:185-7.

9. Wang YJ, Cui GQ. Arthroscopic excision of spinoglenoid notch cyst through two different approaches. Chin Med J (Engl) 2010;123(21):3154-6.

10. Barnes WE, Larsen RD, Posch JL. Review of ganglia of the hand and wrist with analysis of surgical treatment. Plast Reconst Surg 1964;34:570-8. 